\title{
Patterns in target-directed breast cancer research
}

\author{
Sofia Torres ${ }^{1 *}$, Christine Simmons², Jean-François Boileau ${ }^{3}$, Deanna McLeod ${ }^{4}$, Ilidio Martins ${ }^{4}$ \\ and Maureen Trudeau ${ }^{1}$
}

\begin{abstract}
We undertake an analysis of ongoing $B C$ targeted therapy trials registered to CT.gov to describe patterns of ongoing clinical research, highlight gaps in current research programs and identify ways of optimizing ongoing initiatives. A search of clinicaltrials.gov was conducted on September 4, 2013 to identify ongoing randomized phase II and III trials of targeted therapies in BC. A total of 280 trials were analyzed, the majority conducted in either human epidermal growth factor receptor 2 (HER2)-positive $(n=79,28.2 \%$ ) or hormone receptor (HR)-positive ( $n=104$, $37.1 \%)$ populations. Less than half of all trials were conducted in populations selected to match the agent under investigation ( $n=126,45 \%$ ). HER2-directed therapy is the single most investigated class of targeted agents $(n=73$, $26.1 \%)$, but trials investigating anti-angiogenic agents are also common $(n=49,17.5 \%)$. The most common new classes of agents under investigation in HR-positive and triple negative (TN)/BRCA-positive disease, are non-receptor protein kinase-inhibitors ( $n=12 ; 11.5 \%$ ) and poly (ADP-ribose) polymerase inhibitors $(n=6 ; 30 \%$ ), respectively. The majority of regimens combine new targeted agents with either chemotherapy ( $n=164,58.6 \%$ ) or endocrine therapy $(n=113,40.4 \%)$; a total of 8 trials $(2.8 \%)$ investigated peptide-drug conjugates. The most frequently utilized end-points were pathological complete response in the neo-adjuvant setting $(n=36,52.9 \%)$ and time-to-event end-points in the adjuvant and advanced settings ( 77.3 and $72.6 \%$, respectively). Our findings suggest a need for more target-matched agent development, maintenance of a value-based focus in research and a need for the clinical development of agents to treat TN/BRCA-positive and HR-positive BC.
\end{abstract}

Keywords: Clinical trials, Target-directed research, Biomarkers, Patient profiling, Randomized trials, Breast cancer

\section{Background}

Breast cancer $(\mathrm{BC})$ is a significant health concern, with approximately 256,140 new diagnoses of BC in North America annually and 44,720 deaths in 2013 (DeSantis et al. 2013; Canadian Cancer Society's Steering Committee on Cancer Statistics 2013). Over 600 million dollars are invested in BC research in the United States (US) each year by, the National Cancer Institute alone (National Cancer Institute 2013), and female BC has received the highest allotment of US national expenditure for cancer treatment (National Cancer Institute 2012). For over a decade, a main objective of $B C$ research

\footnotetext{
*Correspondence: sofia.torres@sunnybrook.ca

1 Sunnybrook Health Sciences Centre, 2075 Bayview Ave., Room T2 023

Toronto, ON M4N 3M5, Canada

Full list of author information is available at the end of the article
}

has been the development of targeted agents designed to improve outcomes while decreasing toxicity (Jain 2014). Efforts to move from a "one size fits all" to a more personalized approach to therapy have resulted in a substantial, multi-faceted body of research. Examples of some of the more significant research gleanings related to trial populations, interventions and trial design are summarized in Table 1. Prominent among these is the discovery of target-matched treatment strategies, the development of targeted treatments in populations enriched for the biological target of interest [e.g., hormone-receptor (HR) or human epidermal growth factor receptor 2 (HER2)]. Recent data show that wide-spread use of target-matched strategies over the last 15 years have resulted in dramatic improvements in the prognosis of patients with estrogenreceptor (ER)-positive (Early Breast Cancer Trialists' Collaborative Group 2005; Early Breast Cancer Trialists'

\section{黛 Springer}




\section{Table 1 Lessons learned over the past decade of target-directed research in breast cancer}

\begin{tabular}{|c|c|}
\hline Lesson & Examples \\
\hline \multicolumn{2}{|l|}{ Trial populations } \\
\hline $\begin{array}{l}\text { Conduct trials in either positively- } \\
\text { selected }^{\mathrm{a}} \text { or target-matched } \\
\text { populations }\end{array}$ & $\begin{array}{l}\text { Identification of } 6 \text { intrinsic biological BC subtypes (luminal A; luminal B; HER2-enriched; basal-like; normal } \\
\text { breast-like; and claudin-low) (Perou et al. 2000; Sorlie et al. 2001; Carey et al. 2006; Prat et al. 2010) } \\
\text { Recurrence scores (e.g. OncotypeDX, PAM50, MammaPrint or IHC4) to help select patients that can forego } \\
\text { adjuvant CT (Paik et al. 2006; Albain et al. 2010; Paik et al. 2004; Parker et al. 2009; Chia et al. 2012; Barton } \\
\text { et al. 2012; Dowsett et al. 2008; Cuzick et al. 2011; van 't Veer et al. 2002; Cardoso et al. 2008; Rutgers et al. } \\
\text { 2011; van de Vijver et al. 2002) } \\
\text { Positive trial outcomes } \\
\text { HER2-inhibitors in HER2-positive populations (Slamon et al. 2001; Guan et al. 2013; Goldhirsch et al. 2013; } \\
\text { Marty et al. 2005; Perez et al. 2011; Vogel et al. 2002) } \\
\text { ET in HR-positive populations (Fisher et al. 1989; Early Breast Cancer Trialists' Collaborative Group 2005) } \\
\text { Negative trial outcomes } \\
\text { Bevacizumab combinations in HER2-negative populations (Miller et al. 2005, 2007; Miles et al. 2010; Robert } \\
\text { et al. 2011; Brufsky et al. 2011) } \\
\text { Cetuximab combinations in non-KRAS wild-type (Carey et al. 2012; Baselga et al. 2010; O'Shaughnessy et al. } \\
\text { 2007) } \\
\text { Inaparib in triple-negative populations (O'Shaughnessy et al. 2011a) }\end{array}$ \\
\hline
\end{tabular}

Interventions

Consider combining T-D with CT

Consider multi-T-D strategies based on a biological rationale

Consider continued T-D therapy
Trastuzumab plus CT (Goldhirsch et al. 2013; Marty et al. 2005; Perez et al. 2011; Slamon et al. 2001; Inoue et al. 2010; Swain et al. 2013) in HER2-positive populations T-DM1 (Verma et al. 2012) in HER2-positive populations

Everolimus plus ET in HR-positive (Baselga et al. 2012b)

Dual HER2-inhibition in HER2-positive (Baselga et al. 2012c; Swain et al. 2013; Gianni et al. 2012)

\section{Early setting}

Positive trial outcomes

Additional 5 years of tamoxifen (Davies et al. 2013; Gray et al. 2013) or letrozole (Goss et al. 2005) in HRpositive populations

Negative trial outcomes

An additional year of trastuzumab in HER2-positive populations (Goldhirsch et al. 2013)

Advanced setting

Sequential ET in HR-positive populations (Baselga et al. 2012b)

Continued HER2-inhibition in HER2-positive across multiple lines of therapy (Cameron et al. 2008; Verma et al. 2012; von Minckwitz et al. 2009)
Trial design

Consider the neo-adjuvant setting as a platform for accelerated testing ${ }^{c}$

Utilize phase III trials to arrive at conclusive findings

Are powered to assess improved survival ${ }^{d}$
Pertuzumab (Gianni et al. 2012, 2015), trastuzumab plus FEC and paclitaxel (Buzdar et al. 2013) in HER2positive NAT populations

Trastuzumab plus lapatinib (Baselga et al. 2012a; Robidoux et al. 2012) in HER2-positive patient NAT populations

Negative trial outcomes

Iniparib in TN populations (O'Shaughnessy et al. 2011a, b)

Positive trial outcomes

The majority of currently established T-D agents (Baselga et al. 2012b, c; Buzdar et al. 1996, 1998; Cameron et al. 2008; Fisher et al. 1989; Slamon et al. 2001; The Nolvadex Adjuvant Trial Organisation 1985; Verma et al. 2012)

Negative trial outcomes

Bevacizumab combinations in first-line (Miles et al. 2010; Miller et al. 2007; Robert et al. 2011)

Positive trial outcomes

EGF104535 (Guan et al. 2013), CLEOPATRA (Swain et al. 2012; Verma et al. 2012), EMILIA (Baselga et al. 2012c; Swain et al. 2013)

CT chemotherapy, ET endocrine therapy, FEC fluorouracil, epirubicin and cyclophosphamide, HER2 human epidermal growth factor receptor 2, HR hormone receptor, NAT neoadjuvant therapy, OS overall survival, $p C R$ pathological complete response, $T-D$ target-directed therapy, $T-D M 1$ trastuzumab emtansine, $T N$ triple negative

a Patient selection is based on over-expression, mutation or other modification of one or more biomarkers or on a multi-biomarker profile/signature with prognostic or predictive value

b Biomarker used to positively-select patients is targeted by the investigational T-D agent

c Depends on use of pCR as surrogate for survival (pCR translates to disease-free survival and overall survival according to results of the NOAH trial) (Gianni et al. 2013)

$\mathrm{d}$ Overall survival (or surrogate) as primary end-point 
Collaborative Group 1998; Davies et al. 2011) and HER2positive disease (Dawood et al. 2010; Yin et al. 2011; Harris et al. 2011), in both the early and advanced settings. Additionally, the discovery of 6 intrinsic biological BC subtypes (luminal A; luminal B; HER2-enriched; basallike; normal breast-like; and claudin-low) (Perou et al. 2000; Sorlie et al. 2001; Carey et al. 2006; Prat et al. 2010) has reshaped our understanding of disease biology and shifted our current approach to treatment. Treatment decisions are now guided by prognostic and predictive biomarkers [ER, progesterone receptor (PR) and HER2] which define 3 major therapeutic groups: HER2-positive disease ( $20 \%$ of all patients) (Arteaga et al. 2012; Ross et al. 2009), HR-positive disease ( 75\%) (Anderson et al. 2011; Lim et al. 2012; Nadji et al. 2005), and triplenegative disease (TN, neither HER2, ER or PR-positive; $\sim 15 \%$ ) (Foulkes et al. 2010).

The National Institute of Health's clinicaltrials.gov (CT. gov) database is the most robust of international trial registries, serving as both a mandatory repository for information on clinical trials conducted under US regulation and a prerequisite for publishing study results in peer-reviewed journals (Hirsch et al. 2013). Although select data are populated by individual investigators and not always consistently reported, the database represents a unique resource through which to evaluate research. The database currently contains detailed information on more than 5000 clinical trials in $\mathrm{BC}$ from more than 90 countries (ClinicalTrials.gov 2014b), and ranks BC among the most investigated tumor types per incidence (Hirsch et al. 2013). However, given that clinical research in oncology is both costly and associated with the highest rates of drug attrition and trial failure (Begley and Ellis 2012; Hutchinson and Kirk 2011) we have undertaken an analysis of ongoing $\mathrm{BC}$ targeted therapy trials registered to CT.gov to describe patterns of ongoing clinical research, highlight gaps in current research programs and identify ways of optimizing ongoing initiatives.

\section{Results}

\section{Study selection}

A total of 1545 matching records were downloaded for analysis, and 1265 studies were excluded (Fig. 1). The remaining data set of 280 trials was locked and parsed to facilitate analysis.

\section{Populations and classes under development}

The majority of trials were conducted in either HER2positive $(\mathrm{n}=79,28.2 \%)$ or HR-positive $(\mathrm{n}=104$, $37.1 \%$ ) populations (Fig. 2a). Trials conducted in TN/ BRCA-positive disease accounted for $7.1 \%(n=20)$ of all research. Trials in all other populations accounted for $27.5 \%(n=77)$ of research. Less than half of all ongoing trials were conducted in target-matched (i.e., enriched for the biological target of the therapy under investigation) populations ( $\mathrm{n}=126,45.0 \%$; Table 2$)$. The most investigated classes of agents were HER2-inhibitors $(\mathrm{n}=73$, $26.1 \%)$, endocrine agents $(\mathrm{n}=52,18.6 \%)$ and anti-angiogenic agents $(n=49,17.5 \%$; Fig. $2 \mathrm{~b})$. The proportion of research dedicated to the development of emergent agents was only slightly greater than the proportion addressing established agents (52.5 and $47.5 \%$, respectively), and consisted mostly of phase II studies (74.8 \%).

\section{Therapeutic strategies}

The majority of regimens under investigation combined new targeted agents with either chemotherapy $(\mathrm{n}=164$, $58.6 \%$ ) or endocrine therapy (ET, $\mathrm{n}=113,40.4 \%$; Table 2). A total of 8 trials (2.8 \%) investigated peptidedrug conjugates, six trials assessed the HER2 antibodydrug conjugate ado-trastuzumab-emtansine (T-DM1) in HER2-positive disease, one trial tested a luteinizing-hormone-releasing hormone receptor (LHRH-R)antibody conjugate in TN disease (LHRH-R-positive) and one investigated a glycoprotein NMB (GpNMB)directed conjugate in a population selected for GpNMB expression.

A broad range of therapeutic strategies were tested, with most trials investigating a single class of agents (mono-class, $\mathrm{n}=195,69.6 \%$; Table 2), either used alone (single-targeted, $\mathrm{n}=159,81.5 \%$, with or without non-target-directed therapy; Fig. 3a) or in combination with agents from the same class (dual-targeted, $\mathrm{n}=36$, $18.5 \%)$. Of the trials investigating targeted combinations from different classes (multi-class, $\mathrm{n}=85,30.4 \%$; Table 2), most combined two agents (dual-targeted, $\mathrm{n}=78,91.8 \%$; Fig. 3b) and others combined three agents (triple-targeted, $\mathrm{n}=7,8.2 \%$ ).

\section{HER2-positive}

In HER2-positive disease, HER2-inhibitor trials made up $81.0 \%(n=64)$ of ongoing research, while other research was directed toward anti-angiogenics $(\mathrm{n}=5,6.3 \%)$, mammalian target of rapamycin (mTOR)/phosphoinositide 3-kinase (PI3K)/protein kinase B (Akt)-inhibitors $(\mathrm{n}=4,5.1 \%)$ and immunotherapy/vaccines $(\mathrm{n}=4$, $5.1 \%$; Table 2). Mono-class trials $(\mathrm{n}=60,75.9 \%$; Fig. 3a) employed either a single HER2-inhibitor approach $(\mathrm{n}=39,65.0 \%)$ or a dual-HER2-inhibitor approach $(n=20,33.3 \%)$, with the exception of a single HER2 vaccine trial $(\mathrm{n}=1,1.6 \%)$. Multi-class trials $(\mathrm{n}=19,24.1 \%$; Fig. 3b) were generally characterized by HER2-directed therapy combined with either anti-angiogenics $(\mathrm{n}=5$, $26.3 \%)$, ET ( $\mathrm{n}=5,26.3 \%)$ or mTOR-inhibitors $(\mathrm{n}=4$, $21.0 \%$ ). These trials included two conducted in HER2/ HR co-positive populations: one combining ET with a 


\section{Current and Ongoing Randomized Trials of Target-Directed Agents in BC}

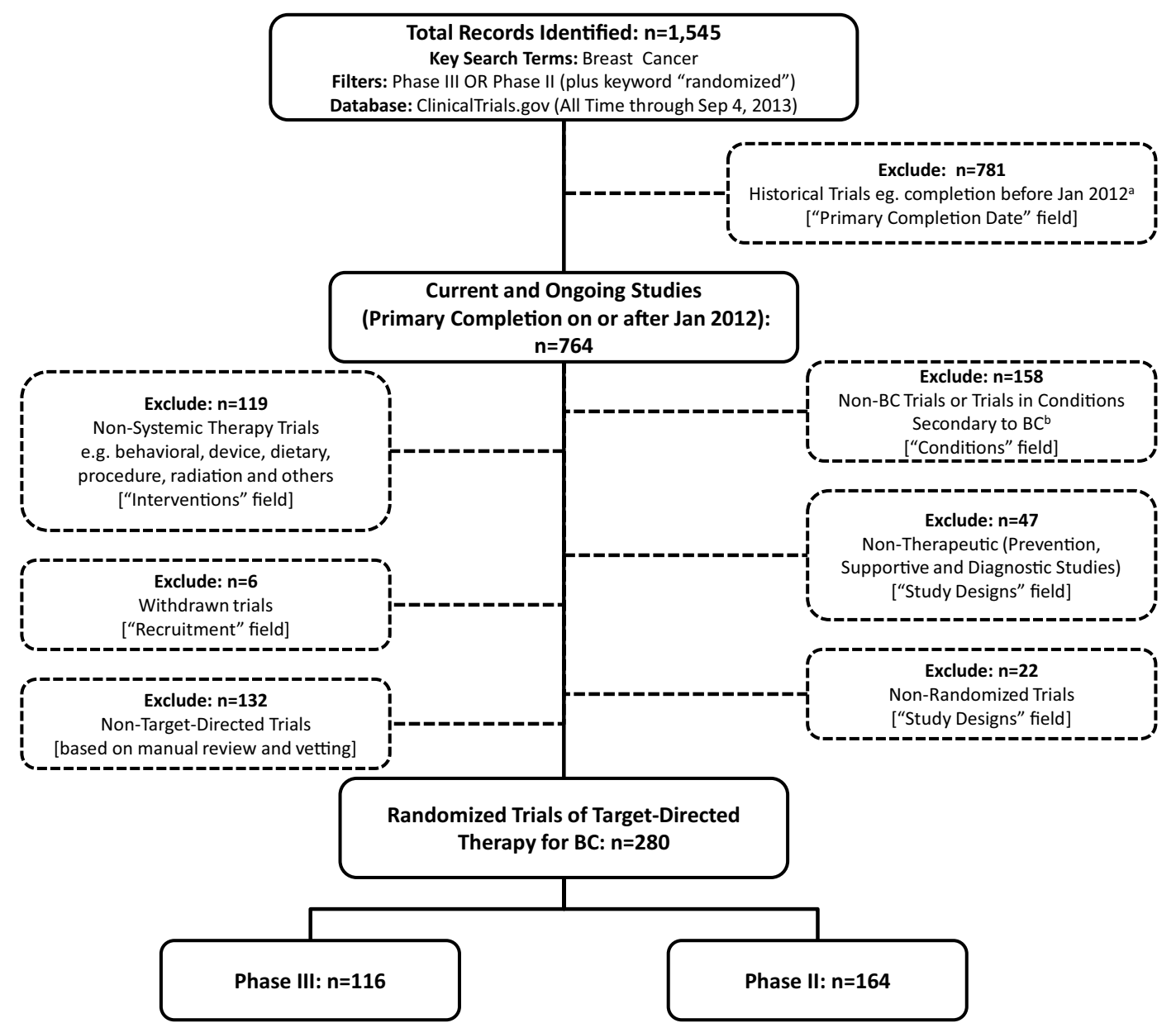

Fig. 1 PRISMA diagram representing screening process and final trial eligibility. ${ }^{2}$ Some trial records did not have a primary completion date $(n=246)$. These trials were deemed not likely to meet the cut-off date and excluded from the database if they met the following criteria: (1) possessed a completion date before January $2012(n=112)$; (2) had completed, terminated or withdrawn status and their records were last verified before January $2012(n=37)$; (3) were not verified by the sponsor in more than 10 years $(n=18)$; 4$)$ possessed a start date before $1998(n=19)$; ${ }^{b}$ Trials in mixed populations were also excluded. BC breast cancer

dual HER2-blockade and another combining ET with a HER2-inhibitor and a HER2 vaccine.

\section{HR-positive}

In HR-positive disease, ET made up $45.2 \%(\mathrm{n}=47$; Table 2) of ongoing research, and $13.5 \%$ was focused on mTOR/PI3K/Akt-inhibitors $(\mathrm{n}=14)$. Other classes under investigation in this area were intracellular, nonreceptor protein kinase $(\mathrm{PK})$-inhibitors $(\mathrm{n}=12,11.5 \%)$ and growth factor-inhibitors $(\mathrm{n}=12,11.5 \%)$. Monoclass trials $(\mathrm{n}=51,49.0 \%$; Fig. 3a) investigating ET therapy $(\mathrm{n}=44,86.3 \%)$ or mTOR pathway-inhibitor therapy $(\mathrm{n}=3,5.9 \%)$ were common. Dual-targeted approaches combined traditional ET, such as tamoxifen- or aromatase-inhibitors with LHRH-R-agonists $(\mathrm{n}=10)$ or androgen receptor (AR)-targeted agents $(n=1)$. Multiclass trials ( $\mathrm{n}=53,51.0 \%$; Fig. $3 \mathrm{~b}$ ) commonly comprised ET in combination with either mTOR/PI3K-inhibitors $(\mathrm{n}=10,18.9 \%)$, anti-angiogenics $(\mathrm{n}=8,15.1 \%)$ or cyclin-dependent kinase 4 and $6(C D K 4 / 6)$-inhibitors $(n=4$, $7.5 \%$ ). A small number of trials also explored a tripletargeted approach $(\mathrm{n}=5,9.4 \%)$, combining CDK4/6inhibitors plus mTOR/PI3K-inhibitors and ET $(\mathrm{n}=2)$, IGF(R)-inhibitors plus either a c-KIT- or mTOR-inhibitor and ET $(n=2)$, or a HER2-inhibitor plus metformin and $\operatorname{ET}(\mathrm{n}=1)$. 


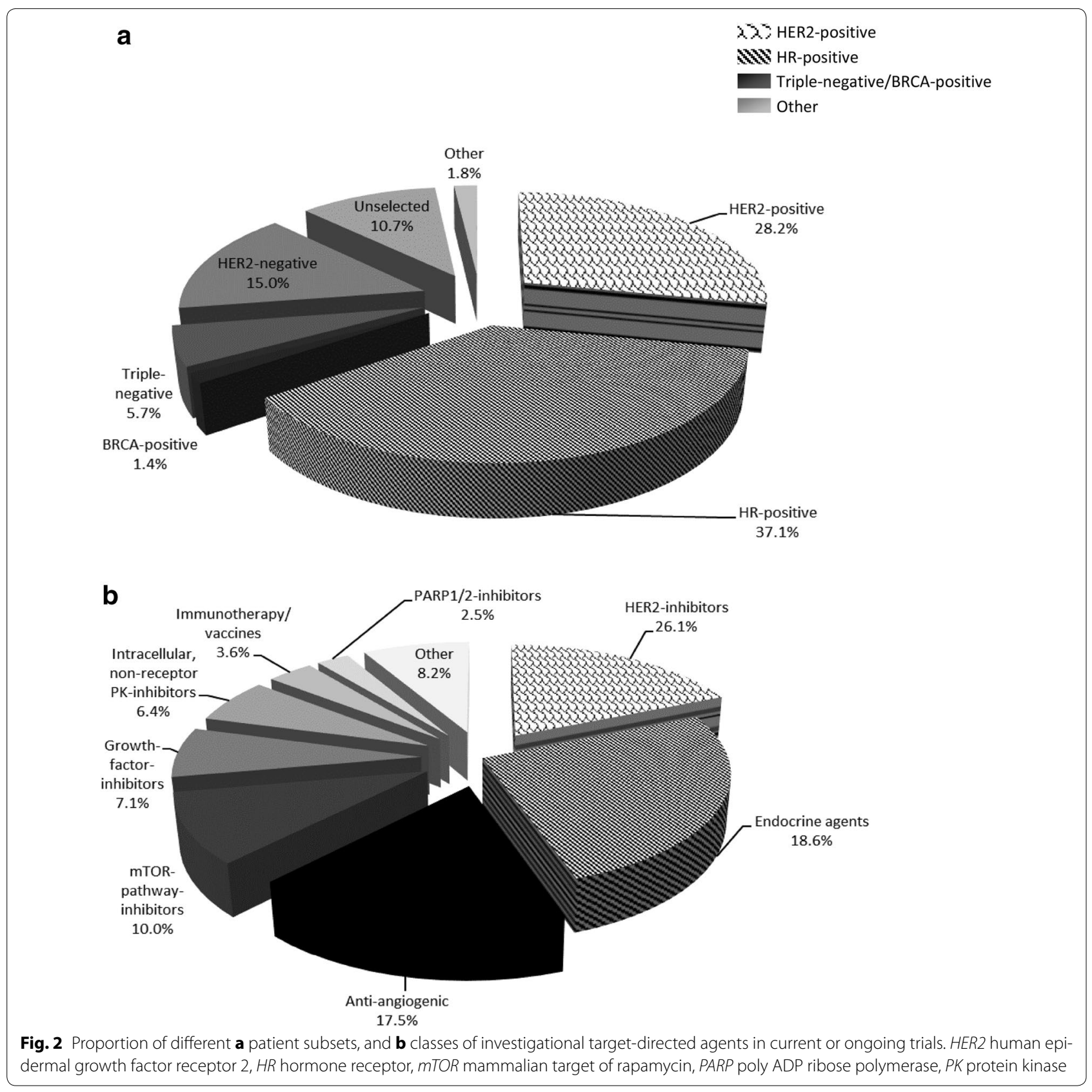

\section{Triple-negative/BRCA-positive}

In TN/BRCA-positive disease, poly(ADP-ribose) polymerase (PARP) 1/2-inhibitors were the most studied class of drugs $(n=6,30.0 \%$; Table 2$)$ followed by antiangiogenics $(\mathrm{n}=4,20.0 \%)$ and mTOR/PI3K/Akt-inhibitors $(\mathrm{n}=3,15.0 \%)$. Mono-class trials $(\mathrm{n}=19,95.0 \%$; Fig. 3a) focused on PARP-inhibitors $(\mathrm{n}=6,31.6 \%$ ), mTOR-inhibitors $(\mathrm{n}=3,15.8 \%)$ and anti-angiogenics $(\mathrm{n}=3,15.8 \%)$. Trials combining multiple classes of agents ( $\mathrm{n}=1,5.0 \%$; Fig. 3b) were less prevalent, with only one combining a c-met-inhibitor and an anti-angiogenic agent.

\section{Other}

In other populations, anti-angiogenics remained a key area of research $(\mathrm{n}=33,42.8 \%$; Table 2). Mono-class trials ( $\mathrm{n}=65,84.4 \%$; Fig. 3a) focused predominantly on anti-angiogenic agents $(\mathrm{n}=32,49.2 \%)$, while some research explored mTOR-inhibitors $(\mathrm{n}=6,9.2 \%)$, HER2-inhibitors $(\mathrm{n}=3,4.6 \%)$, ET $(\mathrm{n}=3,4.6 \%)$, 
Table 2 Randomized trial characteristics by biological subtype of trial population and treatment setting

\begin{tabular}{|c|c|c|c|c|c|}
\hline Categories & $\begin{array}{l}\text { HER2-positive } \\
\text { [n (\%)] }\end{array}$ & $\begin{array}{l}\text { HR-positive } \\
\text { [n (\%)] }\end{array}$ & $\begin{array}{l}\text { Triple-negative or } \\
\text { BRCA-positive [n (\%)] }\end{array}$ & $\begin{array}{l}\text { Other or unselected } \\
\text { [n (\%)] }\end{array}$ & Total [n (\%)] \\
\hline Total, n (proportion by subtype, \%) & $79(28.2)$ & $104(37.1)$ & $20(7.1)$ & $77(27.5)$ & $280(100.0)$ \\
\hline \multicolumn{6}{|l|}{ Populations } \\
\hline Target-matched & $68(86.1)$ & $50(48.1)$ & $1(5.0)$ & $7(9.1)$ & $126(45.0)$ \\
\hline Non target-matched & $11(13.9)$ & $54(51.9)$ & $19(95.0)$ & $70(90.9)$ & $154(55.0)$ \\
\hline \multicolumn{6}{|l|}{ Investigational target-directed classes } \\
\hline HER2-inhibitors & $64(81.0)$ & $4(3.8)$ & $0(0)$ & $5(6.5)$ & $73(26.1)$ \\
\hline Endocrine agents & $0(0)$ & $47(45.2)$ & $1(5.0)$ & $4(5.2)$ & $52(18.6)$ \\
\hline Anti-angiogenics & $5(6.3)$ & $7(6.7)$ & $4(20.0)$ & $33(42.8)$ & $49(17.5)$ \\
\hline mTOR/PI3K/Akt pathway-inhibitors & $4(5.1)$ & $14(13.5)$ & $3(15.0)$ & $7(9.1)$ & $28(10.0)$ \\
\hline Growth factor-inhibitors & $2(2.5)$ & $12(11.5)$ & $2(10.0)$ & $4(5.2)$ & $20(7.1)$ \\
\hline Intracellular, non-receptor PK-inhibitors & $0(0)$ & $12(11.5)$ & $1(5.0)$ & $5(6.5)$ & $18(6.4)$ \\
\hline Immunotherapy/vaccines & $4(5.1)$ & $0(0)$ & $0(0)$ & $6(7.8)$ & $10(3.6)$ \\
\hline PARP1/2-inhibitors & $0(0)$ & $1(1.0)$ & $6(30.0)$ & $0(0)$ & $7(2.5)$ \\
\hline Other & $0(0)$ & $7(6.7)$ & $3(15.0)$ & $13(16.9)$ & $23(8.2)$ \\
\hline \multicolumn{6}{|l|}{ Types of target-directed therapy } \\
\hline Established & $59(74.7)$ & $56(53.8)$ & $2(10.0)$ & $16(20.8)$ & $133(47.5)$ \\
\hline Emergent & $20(25.3)$ & $48(46.2)$ & $18(90.0)$ & $61(79.2)$ & $147(52.5)$ \\
\hline \multicolumn{6}{|l|}{ Therapeutic strategies } \\
\hline Chemotherapy-based regimens & $64(81.0)$ & $13(12.5)$ & $18(90.0)$ & $69(89.6)$ & $164(58.6)$ \\
\hline Non chemotherapy-based regimens & $15(19.0)$ & $91(87.5)$ & $2(10.0)$ & $8(10.4)$ & $116(41.4)$ \\
\hline ET-based regimens & $6(7.6)$ & $95(91.3)$ & $1(5.0)$ & $11(14.3)$ & $113(40.4)$ \\
\hline Non ET-based regimens & $73(92.4)$ & $9(8.6)$ & $19(95.0)$ & $66(85.7)$ & $167(59.6)$ \\
\hline Peptide-drug conjugates & $6(7.6)$ & $0(0)$ & $1(5.0)$ & $1(1.3)$ & $8(2.8)$ \\
\hline Mono-class regimens & $60(75.9)$ & $51(49.0)$ & $19(95.0)$ & $65(84.4)$ & $195(69.6)$ \\
\hline Multi-class regimens & $19(24.0)$ & $53(51.0)$ & $1(5.0)$ & $12(15.6)$ & $85(30.4)$ \\
\hline Categories & \multicolumn{2}{|c|}{ Neoadjuvant [n (\%)] } & Adjuvant [n (\%)] & Advanced [n (\%)] & Total [n (\%)] \\
\hline Total [n (proportion by setting, \%)] & $68(24.3)$ & & $66(23.6)$ & $146(52.1)$ & $280(100.0)$ \\
\hline \multicolumn{6}{|l|}{ Subtype } \\
\hline HER2-positive & $25(36.8)$ & & $19(28.8)$ & $35(23.9)$ & $79(28.2)$ \\
\hline HR-positive & $17(25.0)$ & & $29(43.9)$ & $58(39.7)$ & $104(37.1)$ \\
\hline Triple-negative or BRCA-positive & $7(10.3)$ & & $3(4.5)$ & $10(6.8)$ & $20(7.1)$ \\
\hline Other or unselected & $19(27.9)$ & & $15(22.7)$ & $43(29.4)$ & $77(27.5)$ \\
\hline \multicolumn{6}{|l|}{ Primary endpoint } \\
\hline Overall survival & $0(0)$ & & $1(1.5)$ & $6(4.1)$ & $7(2.5)$ \\
\hline Quality of life & $0(0)$ & & $2(3.0)$ & $1(0.7)$ & $3(1.1)$ \\
\hline Pathological complete response & $36(52.9)$ & & $0(0)$ & $0(0)$ & $36(12.8)$ \\
\hline DFS/RFS/PFS/EFS & $3(4.4)$ & & $51(77.3)$ & $106(72.6)$ & $160(57.1)$ \\
\hline Clinical response & $15(22.0)$ & & $1(1.5)$ & $19(13.0)$ & $35(12.5)$ \\
\hline Biomarker & $10(14.7)$ & & $6(9.1)$ & $2(1.4)$ & $18(6.4)$ \\
\hline Safety and tolerability & $4(5.9)$ & & $3(4.5)$ & $8(5.5)$ & $15(5.4)$ \\
\hline Other & $0(0)$ & & $2(3.0)$ & $4(2.7)$ & $6(2.1)$ \\
\hline \multicolumn{6}{|l|}{ Study Phase } \\
\hline Phase II (\%) & $53(77.9)$ & & 15 (22.7) & $96(65.8)$ & $164(58.6)$ \\
\hline Phase III (\%) & $15(22.0)$ & & $51(77.3)$ & $50(34.2)$ & $116(41.4)$ \\
\hline
\end{tabular}

$D F S$ disease-free survival, EFS event-free survival, $E T$ endocrine therapy, HER2 human epidermal growth factor receptor $2, H R$ hormone receptor, $m T O R$ mammalian target of rapamycin, PARP poly(ADP-ribose) polymerase, PI3K phosphoinositide 3-kinase, PFS progression-free survival, RFS relapse-free survival 
a

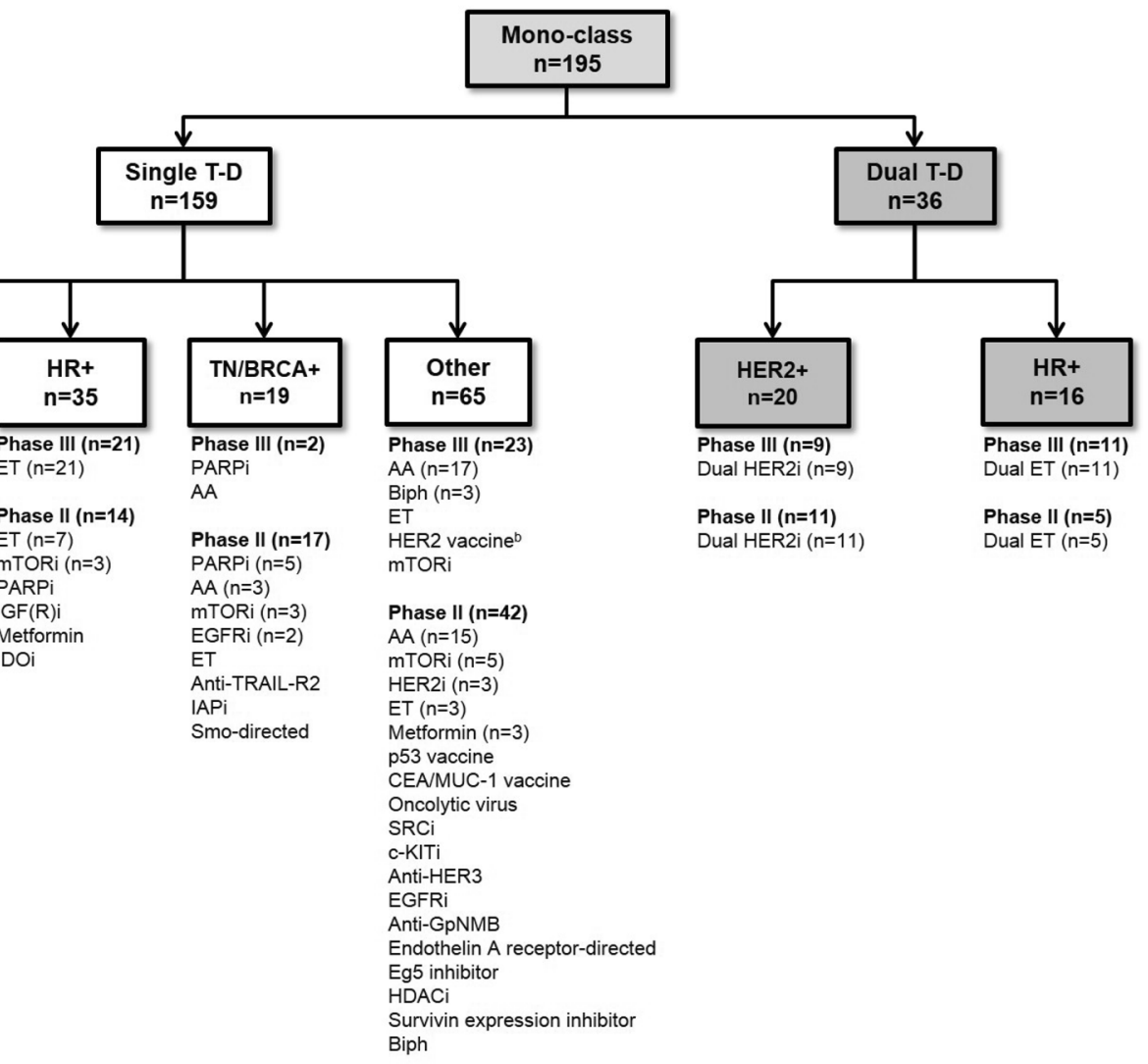

b

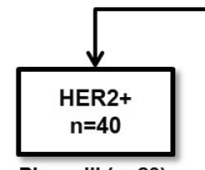

Phase III ( $n=23)$ HER2i $(n=23)$

Phase II $(n=17)$ HER2i $(n=16)$ HER2 vaccine

mTORi $(n=3)$

Anti-TRAIL-R2

Smo-directed
mTORi $(n=5)$

$T(n=3)$

Metformin $(n=3)$

Anti-HER3

Andothelin A receptor-directed

Survivin expression inhibitor

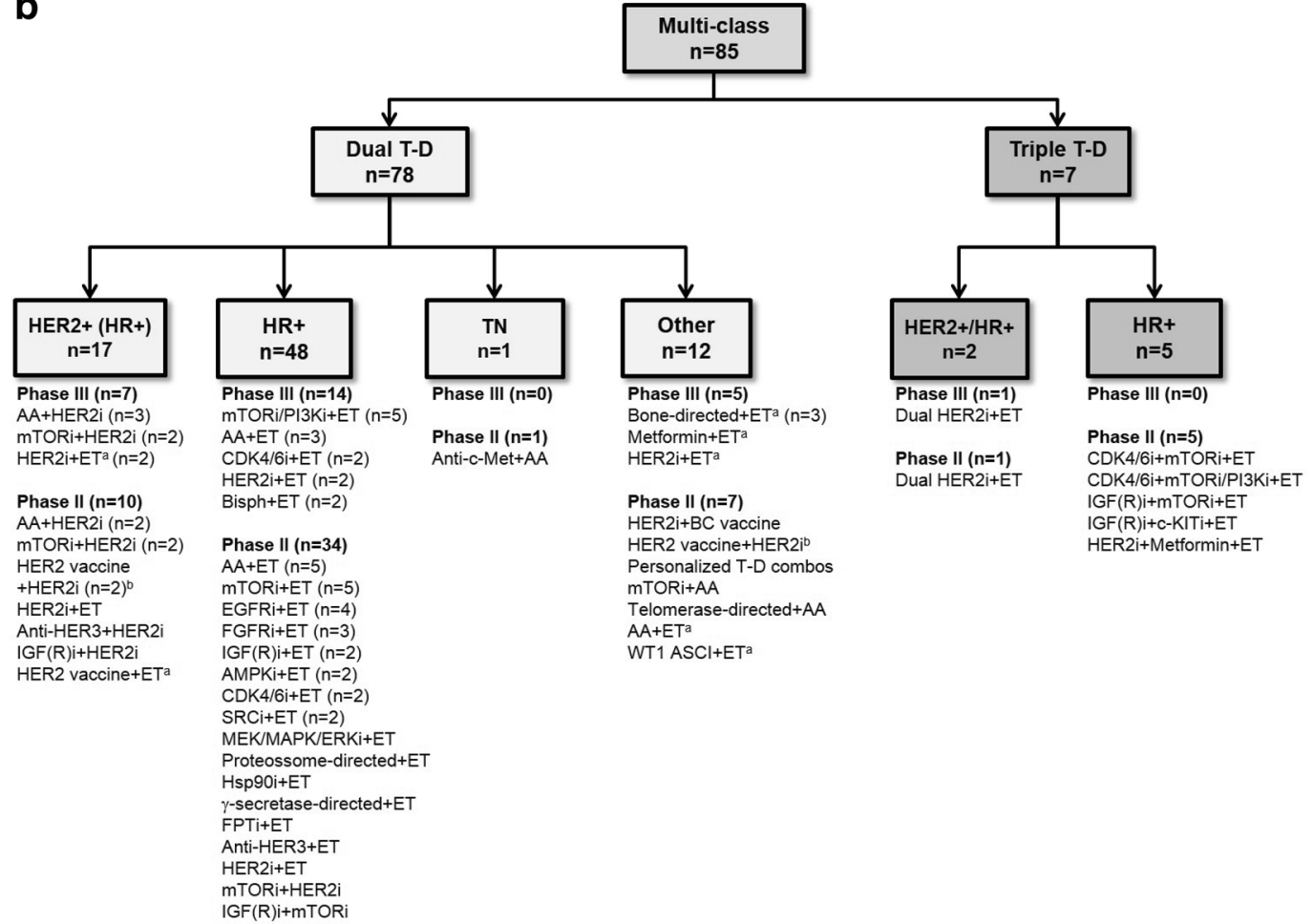


(See figure on previous page.)

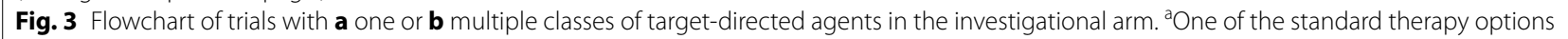
possible. In early (adjuvant and/or neoadjuvant) trials, standard therapy (including ET) may have been required before, during or after the investigational treatment and either before or after surgery. ${ }^{b}$ Trials of HER2 vaccines that included patients with high levels (overexpression) of HER2 (in addition to patients with low and intermediate HER2 levels) were categorized under "HER2-positive" while those that did not include patients overexpressing HER2 were categorized under "Other". Note: When present, non-T-D (including chemotherapy) agents were omitted from the investigational regimen short description. AA anti-angiogenic, AMPKi AMPK inhibitor, ASCI Antigen-Specific Cancer Immunotherapeutic, Bisph bisphosphonates, BRCA + BRCA-positive, CDK4/6i cyclin-dependent kinase 4/6 inhibitor, C-KITi C-KIT (and BCR/Abl and Src or PDGFR) inhibitor, dual T-D experimental regimens containing two target-directed agents, EGFRi epidermal growth factor receptor inhibitor, ET endocrine therapy, FGFRi fibroblast growth factor receptor inhibitor, FPTi farnesyl protein transferase inhibitor, GPNMB glycoprotein NMB, HDACi histone deacetylase inhibitor, HER2 + human epidermal growth factor receptor-positive, HER2i human epidermal growth factor receptor inhibitor, HR + hormone receptor-positive, Hsp90i, heat shock protein 90 inhibitor, IAPi inhibitor of apoptosis inhibitor, IDOi IDO pathway inhibitor, IGF(R)i insulin growth factor (receptor) inhibitor, MEK MAPKJERKi MEK or MAPKJERK inhibitor, mono-class experimental regimens containing only one class of target-directed agents, mTORi mammalian target of rapamycin pathway inhibitor, multi-class experimental regimens containing more than one class of target-directed agents, $P A R P i$ poly(ADPribose) polymerase inhibitor, PI3Ki phosphoinositide 3-kinase inhibitor, Smo smoothened, SRCi SRC kinase family inhibitor, T-D target-directed therapy, TN triple-negative

bisphosphonates ( $\mathrm{n}=3,4.6 \%)$, and metformin $(\mathrm{n}=3$, $4.6 \%)$. Some multi-class research was ongoing $(\mathrm{n}=12$, $15.6 \%$; Fig. 3b), specifically combining bone-directed therapy and ET ( $\mathrm{n}=3,25 \%$ ). Trials of HER2-inhibitors and/or vaccines were also conducted in HER2-negative patients $(n=6)$, including those with low or intermediate levels of HER2 and/or with HER2-expressing disseminated tumor cells.

\section{Setting, primary end-points and trial design}

The majority of ongoing target-directed research was conducted in the advanced setting $(\mathrm{n}=146,52.1 \%)$, with fewer studies in the neo-adjuvant $(\mathrm{n}=68,24.3 \%)$ and adjuvant ( $\mathrm{n}=66,23.6 \%)$ settings (Table 2). In the neo-adjuvant setting, most research was conducted in HER2-positive disease ( $\mathrm{n}=25,36.8 \%$ ), while only $10.3 \%(\mathrm{n}=7)$ was conducted in TN/BRCA-positive populations. Both the total number and proportion of trials conducted in the neo-adjuvant setting in the 5-year period beginning January 2012 increased compared with those of the preceding 5 -year period (2007-2011, $\mathrm{n}=25,16.6 \%$ vs 2012-2016, $\mathrm{n}=58$, $24.6 \%$; Fig. 4). The majority of trials in the adjuvant and advanced settings involved HR-positive $(\mathrm{n}=29,43.9 \%$ and $\mathrm{n}=58,39.7 \%$, respectively; Table 2) and HER2positive populations $(\mathrm{n}=19,28.8 \%$ and $\mathrm{n}=35,23.9 \%$, respectively).

The primary end-points used in targeted trials varied by setting (Table 2 ). In the neo-adjuvant setting, the most common end-points were pathological complete response ( $\mathrm{pCR} ; \mathrm{n}=36,52.9 \%)$, clinical response $(\mathrm{n}=15$, $22.0 \%)$ and biomarker measurement $(\mathrm{n}=10,14.7 \%)$. In the adjuvant and advanced settings, time-to-event end-points were common (77.3 and $72.6 \%$, respectively) while the use of overall survival as a primary end-point in any setting was rare (1.5 and $4.1 \%$, respectively).

There was a slightly greater proportion of phase II trials compared with phase III trials overall $(\mathrm{n}=164,58.6 \%$; Table 2). Phase II trials were most common in the neoadjuvant $(\mathrm{n}=53,77.9 \%)$ and advanced $(\mathrm{n}=96,65.8 \%)$ settings, while phase III trials were more common in the adjuvant setting $(\mathrm{n}=51,77.3 \%)$.

\section{Discussion \\ Populations}

Given the prevalence of expression and demonstrated ability to target HER2 and HRs, the proportion of research dedicated to populations defined by these

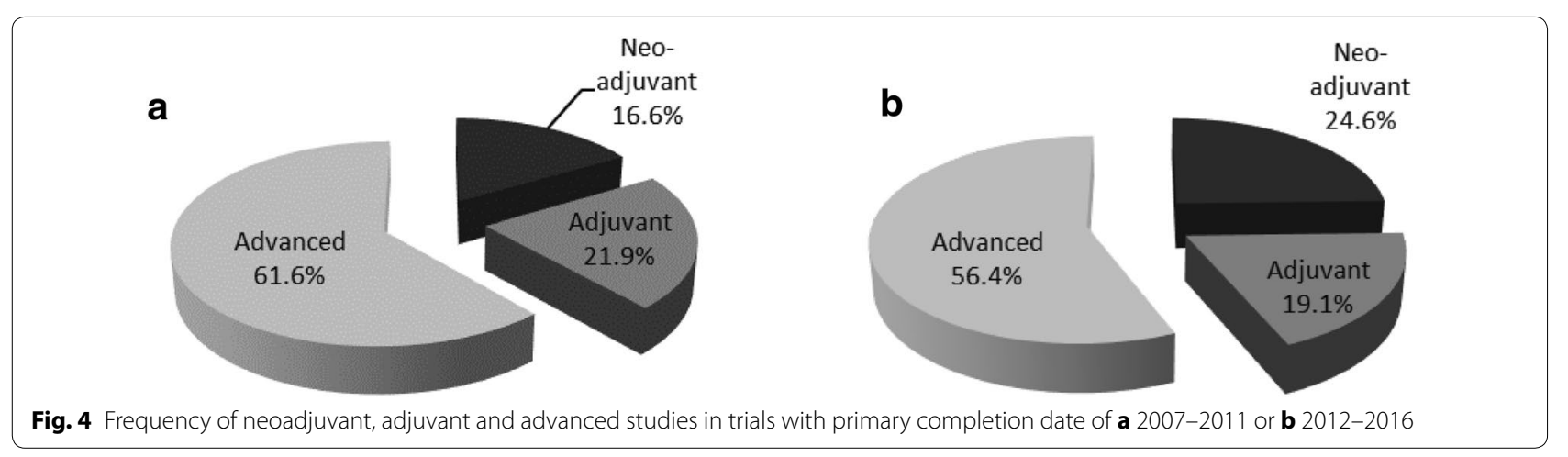


biomarkers is appropriate. However, relative to the overall incidence of HR-positive and TN disease ( $75 \%$ (Lim et al. 2012; Anderson et al. 2011; Nadji et al. 2005) and $\sim 15 \%$ (Foulkes et al. 2010)), the amount clinical development in these settings is low and highlights a need for further research in these settings.

\section{Elimination of chemotherapy}

One of the great promises of targeted therapy was the potential to reduce or eliminate the need for chemotherapy and its indiscriminate effect on normal tissue. However, after more than a decade of research, the majority of trials conducted in non-HR-positive populations ( $\mathrm{n}=151,85.8 \%)$ combine targeted agents with chemotherapy. It is only recently that trials have begun to explore the removal of chemotherapy from targeted regimens for select populations; e.g., eliminating chemotherapy from HER2-directed regimens in elderly adjuvant patients $(\mathrm{n}=1)$ or from dual HER2-targeted combinations in the advanced and neo-adjuvant settings $(n=2)$.

Recurrence scores based on clinicopathological features [e.g., Nottingham Prognostic Index (Blamey et al. 2007), Adjuvant! (Ravdin et al. 2001), and PREDICT (Wishart et al. 2011)] have also been useful in identifying patients who may forego adjuvant chemotherapy. Gene signature-based scores are now being validated in randomized phase III trials in intermediate-risk, HRpositive patients (TAILORx (ClinicalTrials.gov 2014a), RxPONDER (ClinicalTrials.gov 2014d), and MINDACT (ClinicalTrials.gov 2013)), and are expected to further define subsets of patients who may be spared the toxicity of chemotherapy (Viale et al. 2014; Bogaerts et al. 2006). Antibody-cytotoxic conjugates are yet another important means by which chemotherapy-associated adverse effects can be reduced. In HER2-positive disease, a HER2-directed cytotoxic is replacing existing single-agent targeted therapy or cytotoxic-targeted combinations, and a GpNMB-directed cytotoxic is being developed for GpNMB-expressing TN disease (METRIC trial, NCT01997333) (Celldex Therapeutics 2012; ClinicalTrials.gov 2012, 2014c).

\section{Combinatorial strategies}

Effectively targeting oncogenic mutations or copy number alterations has proven challenging, with no new agents identified in the last 15 years. In this context, combinatorial approaches have become one of the most commonly explored strategies. In HER2-positive disease, mono-class regimens combining multiple targeted agents to more effectively block a given receptor have become the focus of ongoing combinatorial research. Dual-HER2-inhibition has held much promise in both the advanced (Baselga et al. 2012c; Verma et al. 2012) and neo-adjuvant (Gianni et al. 2012) settings, yet findings from the ALTTO trial, showing a lack of improvement with the addition of lapatinib to standard adjuvant targeted therapy, calls into question the benefits of this approach in earlier settings (Piccart-Gebhart et al. 2014). Results from the APHINITY trial (NCT01358877), assessing the addition of pertuzumab (rather than lapatinib) to adjuvant targeted therapy, will help clarify the role for combinatorial strategies in early disease.

In HR-positive disease, a main direction of research has been the development of multi-class regimens to inhibit secondary processes, such as treatment resistance (mTOR/PI3K-inhibitors; insulin growth factor receptor $[\operatorname{IGF}(\mathrm{R})]$-inhibitors; epidermal growth factor receptor [EGFR]-inhibitors; fibroblast growth factor receptor [FGFR]-inhibitors), cell cycle regulation (CDK4/6-inhibitors) or effects of the tumor micro-environment (bisphosphonates). Breakthroughs such as the addition of the mTOR-inhibitor everolimus to exemestane in advanced $\mathrm{BC}$ resistant to prior non-steroidal aromatase-inhibitor therapy (Baselga et al. 2012b) and the addition of palbociclib to fulvestrant in patients with advanced BC progressing on prior ET therapy (Turner et al. 2015) illustrate the promise of combinatorial approaches in enhancing established targeted strategies. However, questions of tolerability and cost remain as combinatorial strategies are undertaken to more completely inhibit pro-oncogenic pathways.

\section{Neo-adjuvant setting: platform for accelerated drug development}

The neo-adjuvant setting provides a unique platform for targeted agent research, with opportunities for correlative studies and the potential for translating discovery into benefit in the adjuvant setting. Relative to drug development, improvements in pCR have been correlated with survival outcomes in HER2-positive and TN subtypes (Cortazar et al. 2014) and can be used as the basis for accelerated FDA approval (Prowell and Pazdur 2012). Although the FDA approved pertuzumab in the neoadjuvant setting, the results of the Neosphere trial did not show a statistically significant association between pCR and 3-year disease-free survival and progression-free survival (PFS) (Gianni et al. 2015). The increase in both number and proportion of clinical trials conducted in this setting over the last several years suggests an increased commitment to neo-adjuvant research, although data also suggests that it remains an underutilized strategy.

The negative results of the ALTTO study (PiccartGebhart et al. 2014), evaluating an adjuvant dual-HER2blockade, bring into question the assumption that benefits in the neo-adjuvant setting (Piccart-Gebhart et al. 2013) automatically translate into adjuvant benefits. These 
findings underscore the complexity and challenges of accelerated drug development. Innovative approaches to neo-adjuvant research, using adaptive Bayesian designs and $\mathrm{pCR}$ as the primary end-point, to rapidly select active novel agents (e.g., ISPY2 trial (ClinicalTrials.gov 2015)), may lead to more efficient use of research resources by requiring fewer patients, although absolute magnitudes of benefit are difficult to assess using this type of approach and results require phase III confirmation.

\section{Optimization of research resources}

Although $\mathrm{BC}$ is the most investigated disease site (Hirsch et al. 2013), it is also an area of research associated with one of the highest rates of drug attrition and trial failure (Begley and Ellis 2012; Hutchinson and Kirk 2011). Presently, antiangiogenic agent trials $(\mathrm{n}=49,17.5 \%)$ comprise almost a fifth of all ongoing research, and the total number of these trials is comparable the sum of all ET directed research $(\mathrm{n}=52,18.6 \%)$. Clinical testing of anti-angiogenics in BC has been marked by failure to demonstrate clinically significant PFS and survival benefits and an increased risk of serious side effects (Miles et al. 2010; Robert et al. 2011; Hamburg 2011; Barrios et al. 2010; Baselga et al. 2012d; Mackey et al. 2013). Despite this, as of September 2013, a total of 25,784 patients were accrued to current anti-angiogenic trials, with planned accrual of an additional 3833 patients across 12 trials. A 2006 survey of leading developers estimates that the cost of enrolling a patient into a phase III trial is $\$ 26,000$ (lifesciences world 2006; Stewart et al. 2010). Given these figures, the investment directed toward anti-angiogenic research has amounted to a staggering $\$ 770,042,000$. As the hope of success continues to entice patients and clinicians alike to fully explore the benefits of a given class of therapy, prudence would call for a redirection of resources towards classes of agents that have demonstrated therapeutic benefit or for which a biomarker is available to guide therapy. This is best exemplified in the recent discovery of the 14-gene signature to identify immune-enriched patients who preferentially respond to trastuzumab therapy (Perez et al. 2014).

\section{Conclusions}

Target-directed research is essential to ongoing research efforts in $\mathrm{BC}$ and our understanding of how to optimize these strategies continues to evolve. Our findings suggest that there is a continued need for target-matched agent development, maintenance of a value-based focus in research and a need for the clinical development of agents to treat TN/BRCA-positive and HR-positive BC.

\section{Methods}

\section{Target-directed trial dataset}

A search of the CT.gov website was conducted on September 4, 2013 to identify randomized phase II and III trials of targeted therapies in BC. We considered targeted therapies to be anti-cancer drugs with a clear cellular or molecularly-directed mechanisms of action that interfere with cell growth signaling or tumor blood vessel development, promote death of specific cell types, or stimulate the immune system to destroy specific cell types and/or deliver toxic drugs to cancer cells (National Cancer Institute 2014). All non-randomized, non-systemic, non-therapeutic, or withdrawn trials, as well as those conducted in a non-invasive setting, without a target-directed agent in the experimental arm, or with a primary completion date (date of primary outcome data collection, or date expected) before January 2012, were excluded.

\section{Trial review and classification}

Each trial was classified and analyzed based on the following 9 criteria, which were established based on the record title: (1) degree to which the investigational targeted agent is established (defined below), (2) number and (3) class of targeted agents in the investigational arm, (4) use of continued targeted therapy, (5) setting, (6) biological subtype of population, (7) status of trial, (8) study type and (9) end-points used. If the category was unclear, conditions and key words were assessed or the full CT.gov record was reviewed.

Established targeted-drugs, defined as those with at least one US Food and Drug Administration (FDA)approved BC indication as of September 4, 2013, are summarized in Table 3. Bone-modifying/remodeling agents and progesterone were considered established due to their historical and widespread use in BC treatment; all other agents were defined as emergent. Trials were categorized into 4 mutually exclusive groups based on the biomarker status of the trial population, in order of therapeutic relevance, as follows: HER2positive; HR-positive; TN or BRCA-mutated; (TN/ BRCA-positive); and other populations (HER2-negative trials with HR status unspecified; other subtypes and unselected; not defined by biomarker status).

To assess the degree to which neo-adjuvant trials have changed over the last 5 years, trials with primary completion dates between 2012 and 2016 were compared to those with primary completion dates between 2007 and 2011. 


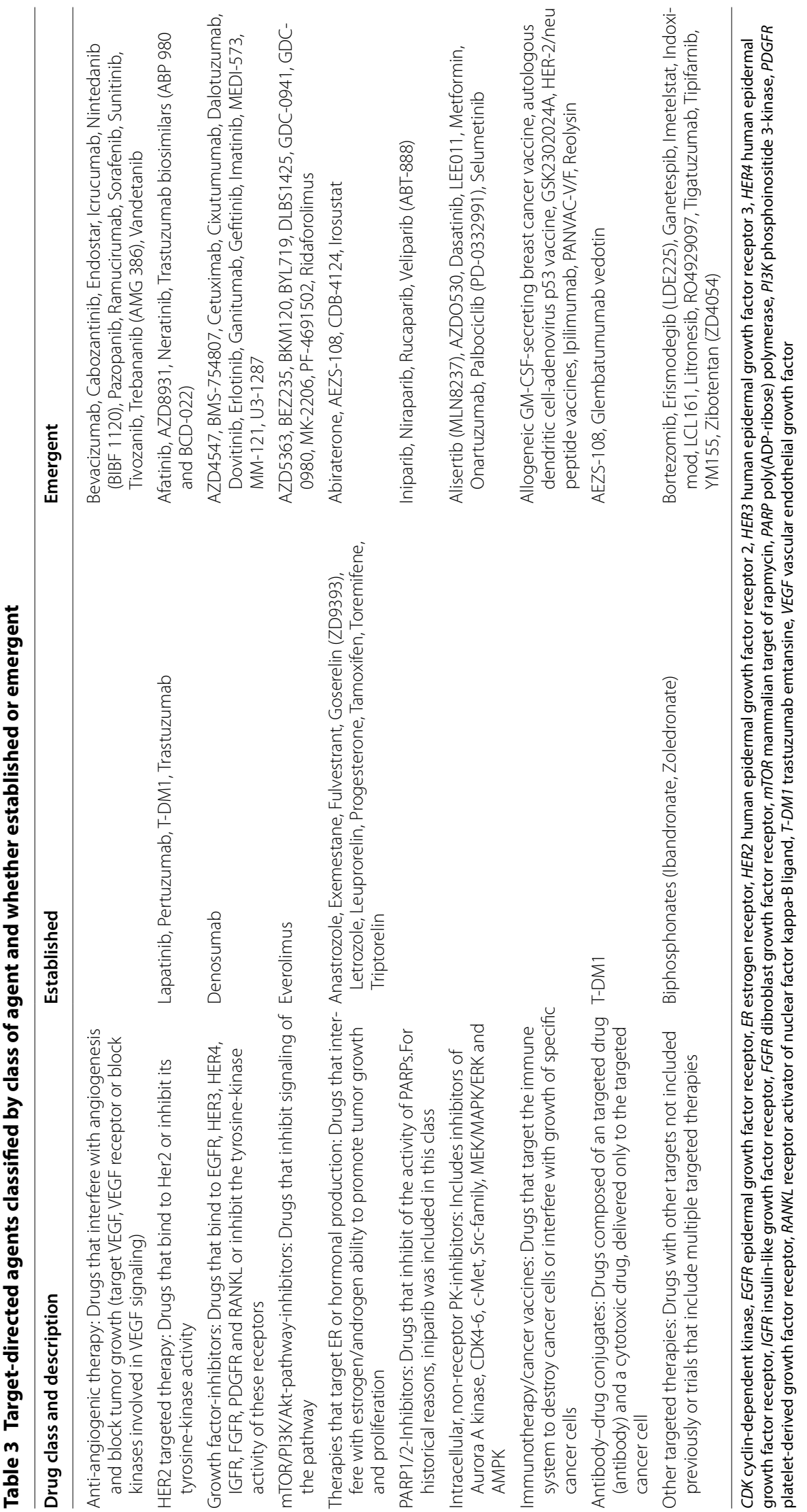




\section{Abbreviations}

Akt: protein kinase B; AR: androgen receptor; BC: breast cancer; CT.gov: clinicaltrials.gov; CDK: cyclin-dependent kinase; EGFR: epidermal growth factor receptor; ER: estrogen receptor; ET: endocrine therapy; FDA: US Food and Drug Administration; FGFR: fibroblast growth factor receptor; GpNMB: glycoprotein NMB; HER2: human epidermal growth factor receptor 2; HR: hormone-receptor; IGFR: insulin growth factor receptor; LHRH-R: luteinizinghormone-releasing hormone receptor; mTOR: mammalian target of rapamycin; PARP: poly(ADP-ribose) polymerase; pCR: pathological complete response; PI3K: phosphoinositide 3-kinase; PR: progesterone receptor; PK: protein kinase; T-DM1: ado-trastuzumab-emtansine; TN: triple-negative; US: United States.

\section{Authors' contributions}

ST, MT, CS, JFB, and DM participated in the study conception and design. MT, DM and IM carried out collection and assembly of data. All authors participated in data analysis and interpretation and writing of the manuscript. All authors read and approved the final manuscript.

\section{Author details}

1 Sunnybrook Health Sciences Centre, 2075 Bayview Ave., Room T2 023, Toronto, ON M4N 3M5, Canada. ${ }^{2}$ British Columbia Cancer Agency, 600 West 10th Avenue, Vancouver, BC V5Z 4E6, Canada. ${ }^{3}$ Jewish General Hospital Segal Cancer Centre, 3755 Côte-Ste-Catherine Road, Montreal, QC, Canada. ${ }^{4}$ Kaleidoscope Strategic, 146 Marion Street, Toronto, ON M6R 1E7, Canada.

\section{Acknowledgements}

We thank Loretta Collins of Kaleidoscope Strategic for editorial assistance in preparing the manuscript.

\section{Competing interests}

Sofia Torres has received honoraria from BMS, payment for travel, accommodations or other expenses from BMS, Roche Farmaceutica Quimica, Celldex and Astra-Zeneca and has received fellowship support from Genomic Health. Christine Simmons has received honoraria from and has been a consultant or advisor for Roche, Novartis, Amgen, and AZ, payment for travel, accommodations or other expenses from Roche, Amgen and Novartis and has received research funding from Roche, Novartis, Amgen, GSK and AZ. Jean-Francois Boileau is a consultant for Roche and Genomic Health, has received honoraria from Roche and Genomic Health, payment for travel, accommodations or other expenses from Roche and Dr. Boileau's institution has received research funding from Rna Diagnostics. Deanna McLeod has stock or other ownership of Immunogen, Seattle Genetics, and Celdex, received research funding from Novartis and has consulted for sanofi. Ilidio Martins is an agent of Kaleidoscope Strategic, which has received research funding from Novartis for the preparation of this manuscript. Maureen Trudeau has stock or other ownership of RNA Diagnostics, has been a consultant or advisor for RNA Diagnostics, has received honoraria from Roche, payment for travel, accommodations or other expenses from Roche, and Dr. Trudeau's institution has received research funding from Amgen, Astra-Zeneca, Novartis, Pfizer, RNA Diagnostics, Roche and sanofi.

\section{Funding source}

This work was funded through an educational grant from Novartis. An independent medical communications management firm, Kaleidoscope Strategic, provided authors with editorial and research assistance. The opinions presented in the paper are those of the authors and not of the sponsor, and authors are prepared to defend their views publically. The sponsor was not involved in any aspect of manuscript development or in the decision to submit the article for publication.

Received: 15 January 2016 Accepted: 18 January 2016 Published online: 01 February 2016

\section{References}

Albain KS, Barlow WE, Shak S, Hortobagyi GN, Livingston RB, Yeh IT, Ravdin P, Bugarini R, Baehner FL, Davidson NE, Sledge GW, Winer EP, Hudis C, Ingle JN, Perez EA, Pritchard KI, Shepherd L, Gralow JR, Yoshizawa C, Allred DC, Osborne CK, Hayes DF (2010) Prognostic and predictive value of the 21-gene recurrence score assay in postmenopausal women with nodepositive, oestrogen-receptor-positive breast cancer on chemotherapy: a retrospective analysis of a randomised trial. Lancet Oncol 11(1):55-65

Anderson WF, Katki HA, Rosenberg PS (2011) Incidence of breast cancer in the United States: current and future trends. J Natl Cancer Inst 103(18):1397-1402

Arteaga CL, Sliwkowski MX, Osborne CK, Perez EA, Puglisi F, Gianni L (2012) Treatment of HER2-positive breast cancer: current status and future perspectives. Nat Rev Clin Oncol 9(1):16-32

Barrios CH, Liu MC, Lee SC, Vanlemmens L, Ferrero JM, Tabei T, Pivot X, Iwata H, Aogi K, Lugo-Quintana R, Harbeck N, Brickman MJ, Zhang K, Kern KA, Martin M (2010) Phase III randomized trial of sunitinib versus capecitabine in patients with previously treated HER2-negative advanced breast cancer. Breast Cancer Res Treat 121(1):121-131

Barton S, Zabaglo L, A'Hern R, Turner N, Ferguson T, O'Neill S, Hills M, Smith I, Dowsett M (2012) Assessment of the contribution of the IHC4 + C score to decision making in clinical practice in early breast cancer. Br J Cancer 106(11):1760-1765

Baselga J, Stemmer S, Pego A, Chan A, Goeminne J, Graas M, Kennedy J, Ciruelos Gil E, Zubel A, Groos J (2010) Cetuximab + cisplatin in estrogen receptor-negative, progesterone receptor-negative, HER2-negative (triple-negative) metastatic breast cancer: results of the randomized phase II BALI-1 trial. Cancer Res 70(24 Suppl):95s

Baselga J, Bradbury I, Eidtmann H, Di Cosimo S, de Azambuja E, Aura C, Gomez H, Dinh P, Fauria K, Van Dooren V, Aktan G, Goldhirsch A, Chang TW, Horvath Z, Coccia-Portugal M, Domont J, Tseng LM, Kunz G, Sohn JH, Semiglazov V, Lerzo G, Palacova M, Probachai V, Pusztai L, Untch M, Gelber RD, Piccart-Gebhart M (2012a) Lapatinib with trastuzumab for HER2-positive early breast cancer (NeoALTTO): a randomised, open-label, multicentre, phase 3 trial. Lancet 379(9816):633-640

Baselga J, Campone M, Piccart M, Burris HA III, Rugo HS, Sahmoud T, Noguchi S, Gnant M, Pritchard KI, Lebrun F, Beck JT, Ito Y, Yardley D, Deleu I, Perez A, Bachelot T, Vittori L, Xu Z, Mukhopadhyay P, Lebwohl D, Hortobagyi GN (2012b) Everolimus in postmenopausal hormone-receptor-positive advanced breast cancer. N Engl J Med 366(6):520-529

Baselga J, Cortes J, Kim SB, Im SA, Hegg R, Im YH, Roman L, Pedrini JL, Pienkowski T, Knott A, Clark E, Benyunes MC, Ross G, Swain SM (2012C) Pertuzumab plus trastuzumab plus docetaxel for metastatic breast cancer. N Engl J Med 366(2):109-119

Baselga J, Segalla JG, Roche H, Del Giglio A, Pinczowski H, Ciruelos EM, Filho SC, Gomez P, Van Eyll B, Bermejo B, Llombart A, Garicochea B, Duran MA, Hoff PM, Espie M, de Moraes AA, Ribeiro RA, Mathias C, Gil Gil M, Ojeda B, Morales J, Kwon Ro S, Li S, Costa F (2012d) Sorafenib in combination with capecitabine: an oral regimen for patients with HER2-negative locally advanced or metastatic breast cancer. J Clin Oncol 30(13):1484-1491

Begley CG, Ellis LM (2012) Drug development: Raise standards for preclinical cancer research. Nature 483(7391):531-533

Blamey RW, Pinder SE, Ball GR, Ellis IO, Elston CW, Mitchell MJ, Haybittle JL (2007) Reading the prognosis of the individual with breast cancer. Eur J Cancer 43(10):1545-1547

Bogaerts J, Cardoso F, Buyse M, Braga S, Loi S, Harrison JA, Bines J, Mook S, Decker N, Ravdin P, Therasse P, Rutgers E, van't Veer LJ, Piccart M (2006) Gene signature evaluation as a prognostic tool: challenges in the design of the MINDACT trial. Nat Clin Pract Oncol 3(10):540-551

Brufsky AM, Hurvitz S, Perez E, Swamy R, Valero V, O'Neill V, Rugo HS (2011) RIBBON-2: a randomized, double-blind, placebo-controlled, phase III trial evaluating the efficacy and safety of bevacizumab in combination with chemotherapy for second-line treatment of human epidermal growth factor receptor 2-negative metastatic breast cancer. J Clin Oncol 29(32):4286-4293

Buzdar A, Jonat W, Howell A, Jones SE, Blomqvist C, Vogel CL, Eiermann W, Wolter JM, Azab M, Webster A, Plourde PV (1996) Anastrozole, a potent and selective aromatase inhibitor, versus megestrol acetate in postmenopausal women with advanced breast cancer: results of overview analysis of two phase III trials. Arimidex Study Group. J Clin Oncol 14(7):2000-2011

Buzdar AU, Jonat W, Howell A, Jones SE, Blomqvist CP, Vogel CL, Eiermann W, Wolter JM, Steinberg M, Webster A, Lee D (1998) Anastrozole versus megestrol acetate in the treatment of postmenopausal women with advanced breast carcinoma: results of a survival update based on a combined analysis of data from two mature phase III trials. Arimidex Study Group. Cancer 83(6):1142-1152 
Buzdar AU, Suman VJ, Meric-Bernstam F, Leitch AM, Ellis MJ, Boughey JC, Unzeitig G, Royce M, McCall LM, Ewer MS, Hunt KK (2013) Fluorouracil, epirubicin, and cyclophosphamide (FEC-75) followed by paclitaxel plus trastuzumab versus paclitaxel plus trastuzumab followed by FEC-75 plus trastuzumab as neoadjuvant treatment for patients with HER2-positive breast cancer (Z1041): a randomised, controlled, phase 3 trial. Lancet Oncol 14(13):1317-1325

Cameron D, Casey M, Press M, Lindquist D, Pienkowski T, Romieu CG, Chan S, Jagiello-Gruszfeld A, Kaufman B, Crown J, Chan A, Campone M, Viens P, Davidson N, Gorbounova V, Raats JI, Skarlos D, Newstat B, Roychowdhury D, Paoletti P, Oliva C, Rubin S, Stein S, Geyer CE (2008) A phase III randomized comparison of lapatinib plus capecitabine versus capecitabine alone in women with advanced breast cancer that has progressed on trastuzumab: updated efficacy and biomarker analyses. Breast Cancer Res Treat 112(3):533-543

Canadian Cancer Society's Steering Committee on Cancer Statistics (2013) Canadian cancer statistics 2013. Canadian Cancer Society, Toronto, ON. http://www.cancer.ca/ /media/cancer.ca/CW/cancer\%20information/ cancer\%20101/Canadian\%20cancer\%20statistics/canadian-cancer-statistics-2013-EN.pdf. Accessed 23 Aug 2013

Cardoso F, Van't Veer L, Rutgers E, Loi S, Mook S, Piccart-Gebhart MJ (2008) Clinical application of the 70-gene profile: the MINDACT trial. J Clin Oncol 26(5):729-735

Carey LA, Perou CM, Livasy CA, Dressler LG, Cowan D, Conway K, Karaca G, Troester MA, Tse CK, Edmiston S, Deming SL, Geradts J, Cheang MC, Nielsen TO, Moorman PG, Earp HS, Millikan RC (2006) Race, breast cancer subtypes, and survival in the Carolina breast cancer study. JAMA 295(21):2492-2502

Carey LA, Rugo HS, Marcom PK, Mayer EL, Esteva FJ, Ma CX, Liu MC, Storniolo AM, Rimawi MF, Forero-Torres A, Wolff AC, Hobday TJ, Ivanova A, Chiu WK, Ferraro M, Burrows E, Bernard PS, Hoadley KA, Perou CM, Winer EP (2012) TBCRC 001: randomized phase II study of cetuximab in combination with carboplatin in stage IV triple-negative breast cancer. J Clin Oncol 30(21):2615-2623

Celldex Therapeutics (2012) Final data from Celldex Therapeutic's CDX-011 phase 2 study in metastatic breast cancer supports overall survival benefit in patients with high GPNMB expression. Celldex Therapeutics. http://ir.celldex.com/releasedetail.cfm?ReleaselD=725688. Accessed 29 May 2014

Chia SK, Bramwell VH, Tu D, Shepherd LE, Jiang S, Vickery T, Mardis E, Leung S, Ung K, Pritchard KI, Parker JS, Bernard PS, Perou CM, Ellis MJ, Nielsen TO (2012) A 50-gene intrinsic subtype classifier for prognosis and prediction of benefit from adjuvant tamoxifen. Clin Cancer Res 18(16):4465-4472

ClinicalTrials.gov (2012) A study of CDX-011 (CR011-vCMMAE) in patients with advanced GPNMB-expressing breast cancer (EMERGE). ClinicalTrials.gov. http://clinicaltrials.gov/ct2/show/NCT01156753. Accessed 29 May 2014

ClinicalTrials.gov (2013) Genetic testing or clinical assessment in determining the need for chemotherapy in women with breast cancer that involves no more than 3 lymph nodes. ClinicalTrials.gov. http://clinicaltrials.gov/ show/NCT00433589. Accessed 29 May 2014

ClinicalTrials.gov (2014a) Hormone therapy with or without combination chemotherapy in treating women who have undergone surgery for node-negative breast cancer (The TAILORx Trial). ClinicalTrials.gov. http:// clinicaltrials.gov/show/NCT00310180. Accessed 11 Sept 2014

ClinicalTrials.gov (2014b) Search: conditions = "breast cancer". http://clinicaltrials.gov/ct2/results/map?cond=breast+cancer. Accessed 20 May 2014

ClinicalTrials.gov (2014c) Study of glembatumumab vedotin (CDX-011) in patients with metastatic, gpNMB over-expressing, triple negative breast cancer (METRIC). ClinicalTrials.gov. http://clinicaltrials.gov/show/ NCT01997333. Accessed 29 May 2014

ClinicalTrials.gov (2014d) Tamoxifen citrate, letrozole, anastrozole, or exemestane with or without chemotherapy in treating patients with invasive RxPONDER breast cancer. ClinicalTrials.gov. http://clinicaltrials.gov/show/ NCT01272037. Accessed 11 Sept 2014

ClinicalTrials.gov (2015) I-SPY 2 TRIAL: neoadjuvant and personalized adaptive novel agents to treat breast cancer. ClinicalTrials.gov. https://clinicaltrials. gov/ct2/show/NCT01042379. Accessed 24 Aug 2015

Cortazar P, Zhang L, Untch M, Mehta K, Costantino JP, Wolmark N, Bonnefoi H, Cameron D, Gianni L, Valagussa P, Swain SM, Prowell T, Loibl S, Wickerham DL, Bogaerts J, Baselga J, Perou C, Blumenthal G, Blohmer J, Mamounas EP, Bergh J, Semiglazov V, Justice R, Eidtmann H, Paik S, Piccart M, Sridhara
R, Fasching PA, Slaets L, Tang S, Gerber B, Geyer CE Jr, Pazdur R, Ditsch N, Rastogi P, Eiermann W, von Minckwitz G (2014) Pathological complete response and long-term clinical benefit in breast cancer: the CTNeoBC pooled analysis. Lancet 384(9938):164-172

Cuzick J, Dowsett M, Pineda S, Wale C, Salter J, Quinn E, Zabaglo L, Mallon E, Green AR, Ellis IO, Howell A, Buzdar AU, Forbes JF (2011) Prognostic value of a combined estrogen receptor, progesterone receptor, Ki-67, and human epidermal growth factor receptor 2 immunohistochemical score and comparison with the Genomic Health recurrence score in early breast cancer. J Clin Oncol 29(32):4273-4278

Davies C, Godwin J, Gray R, Clarke M, Cutter D, Darby S, McGale P, Pan HC, Taylor C, Wang YC, Dowsett M, Ingle J, Peto R (2011) Relevance of breast cancer hormone receptors and other factors to the efficacy of adjuvant tamoxifen: patient-level meta-analysis of randomised trials. Lancet 378(9793):771-784

Davies C, Pan H, Godwin J, Gray R, Arriagada R, Raina V, Abraham M, Medeiros Alencar VH, Badran A, Bonfill X, Bradbury J, Clarke M, Collins R, Davis SR, Delmestri A, Forbes JF, Haddad P, Hou MF, Inbar M, Khaled H, Kielanowska J, Kwan WH, Mathew BS, Mittra I, Muller B, Nicolucci A, Peralta O, Pernas F, Petruzelka L, Pienkowski T, Radhika R, Rajan B, Rubach MT, Tort S, Urrutia G, Valentini M, Wang Y, Peto R (2013) Long-term effects of continuing adjuvant tamoxifen to 10 years versus stopping at 5 years after diagnosis of oestrogen receptor-positive breast cancer: ATLAS, a randomised trial. Lancet 381(9869):805-816

Dawood S, Broglio K, Buzdar AU, Hortobagyi GN, Giordano SH (2010) Prognosis of women with metastatic breast cancer by HER2 status and trastuzumab treatment: an institutional-based review. J Clin Oncol 28(1):92-98

DeSantis C, Ma J, Bryan L (2013) Jemal A (2014) Breast cancer statistics. CA Cancer J Clin 64(1):52-62

Dowsett M, Allred C, Knox J, Quinn E, Salter J, Wale C, Cuzick J, Houghton J, Williams N, Mallon E, Bishop H, Ellis I, Larsimont D, Sasano H, Carder P, Cussac AL, Knox F, Speirs V, Forbes J, Buzdar A (2008) Relationship between quantitative estrogen and progesterone receptor expression and human epidermal growth factor receptor 2 (HER-2) status with recurrence in the Arimidex, Tamoxifen, alone or in combination trial. J Clin Oncol 26(7):1059-1065

Early Breast Cancer Trialists' Collaborative Group (1998) Tamoxifen for early breast cancer: an overview of the randomised trials. Lancet 351(9114):1451-1467

Early Breast Cancer Trialists' Collaborative Group (2005) Effects of chemotherapy and hormonal therapy for early breast cancer on recurrence and 15-year survival: an overview of the randomised trials. Lancet 365(9472):1687-1717

Fisher B, Costantino J, Redmond C, Poisson R, Bowman D, Couture J, Dimitrov NV, Wolmark N, Wickerham DL, Fisher ER et al (1989) A randomized clinical trial evaluating tamoxifen in the treatment of patients with nodenegative breast cancer who have estrogen-receptor-positive tumors. N Engl J Med 320(8):479-484

Foulkes WD, Smith IE, Reis-Filho JS (2010) Triple-negative breast cancer. N Engl J Med 363(20):1938-1948

Gianni L, Pienkowski T, Im YH, Roman L, Tseng LM, Liu MC, Lluch A, Staroslawska E, de la Haba-Rodriguez J, Im SA, Pedrini JL, Poirier B, Morandi P, Semiglazov V, Srimuninnimit V, Bianchi G, Szado T, Ratnayake J, Ross G, Valagussa P (2012) Efficacy and safety of neoadjuvant pertuzumab and trastuzumab in women with locally advanced, inflammatory, or early HER2-positive breast cancer (NeoSphere): a randomised multicentre, open-label, phase 2 trial. Lancet Oncol 13(1):25-32

Gianni L, Eiermann W, Semiglazov V, Manikhas A, Lluch A, Tjulandin S, Zambetti M, Vazquez F, Byakhov M, Lichinitser M (2013) Follow-up results of NOAH, a randomized phase III trial evaluating neoadjuvant chemotherapy with trastuzumab $(\mathrm{CT}+\mathrm{H})$ followed by adjuvant $\mathrm{H}$ versus $\mathrm{CT}$ alone, in patients with HER2-positive locally advanced breast cancer. J Clin Oncol 31(15 suppl):abstr 503

Gianni L, Pienkowski T, Im Y-H, Tseng L-M, Liu M-C, Lluch A, Staroslawska E, de la Haba-Rodriguez J, Im S-A, Pedrini JL, Poirier B, Morandi P, Semiglazov V, Srimuninnimit V, Bianchi GV, McNally V, Douthwaite H, Ross G, Valagussa P (2015) Five-year analysis of the phase II NeoSphere trial evaluating four cycles of neoadjuvant docetaxel (D) and/or trastuzumab (T) and/or pertuzumab (P). ASCO Meet Abstr 33(15 suppl):505

Goldhirsch A, Gelber RD, Piccart-Gebhart MJ, de Azambuja E, Procter M, Suter TM, Jackisch C, Cameron D, Weber HA, Heinzmann D, Dal Lago L, 
McFadden E, Dowsett M, Untch M, Gianni L, Bell R, Kohne CH, Vindevoghel A, Andersson M, Brunt AM, Otero-Reyes D, Song S, Smith I, Leyland-Jones B, Baselga J (2013) 2 years versus 1 year of adjuvant trastuzumab for HER2-positive breast cancer (HERA): an open-label, randomised controlled trial. Lancet 382(9897):1021-1028

Goss PE, Ingle JN, Martino S, Robert NJ, Muss HB, Piccart MJ, Castiglione M, Tu D, Shepherd LE, Pritchard KI, Livingston RB, Davidson NE, Norton L, Perez EA, Abrams JS, Cameron DA, Palmer MJ, Pater JL (2005) Randomized trial of letrozole following tamoxifen as extended adjuvant therapy in receptor-positive breast cancer: updated findings from NCIC CTG MA.17 J Natl Cancer Inst 97(17):1262-1271

Gray R, Rea D, Handley K, Bowden S, Perry P, Earl H (2013) aTTom: long-term effects of continuing adjuvant tamoxifen to 10 years versus stopping at 5 years in 6,953 women with early breast cancer. J Clin Oncol 31:5

Guan Z, Xu B, Desilvio ML, Shen Z, Arpornwirat W, Tong Z, Lorvidhaya V, Jiang Z, Yang J, Makhson A, Leung WL, Russo MW, Newstat B, Wang L, Chen G, Oliva C, Gomez H (2013) Randomized trial of lapatinib versus placebo added to paclitaxel in the treatment of human epidermal growth factor receptor 2-overexpressing metastatic breast cancer. J Clin Oncol 31(16):1947-1953

Hamburg MA (2011) Proposal to withdraw approval for the breast cancer indication for AVASTIN (bevacizumab): decision of the commissioner. Department of Health and Human Services, U.S. Food and Drug Administration. http://www.fda.gov/downloads/NewsEvents/Newsroom/UCM280546. pdf. Accessed 28 May 2014

Harris CA, Ward RL, Dobbins TA, Drew AK, Pearson S (2011) The efficacy of HER2-targeted agents in metastatic breast cancer: a meta-analysis. Ann Oncol 22(6):1308-1317

Hirsch BR, Califf RM, Cheng SK, Tasneem A, Horton J, Chiswell K, Schulman KA, Dilts DM, Abernethy AP (2013) Characteristics of oncology clinical trials: insights from a systematic analysis of ClinicalTrials.gov. JAMA Intern Med 173(11):972-979

Hutchinson L, Kirk R (2011) High drug attrition rates-where are we going wrong? Nat Rev Clin Oncol 8(4):189-190

Inoue K, Nakagami K, Mizutani M, Hozumi Y, Fujiwara Y, Masuda N, Tsukamoto F, Saito M, Miura S, Eguchi K, Shinkai T, Ando M, Watanabe T, Masuda N, Ohashi Y, Sano M, Noguchi S (2010) Randomized phase III trial of trastuzumab monotherapy followed by trastuzumab plus docetaxel versus trastuzumab plus docetaxel as first-line therapy in patients with HER2-positive metastatic breast cancer: the JO17360 Trial Group. Breast Cancer Res Treat 119(1):127-136

Jain KK (2014) Personalized Cancer Therapy. Applications of Biotechnology in Oncology. Springer, Berlin, pp 671-824

Lifesciences World (2006) Phase 3 clinical trial costs exceed $\$ 26,000$ per patient. http://www.lifesciencesworld.com/news/view/11080. Accessed 28 May 2014

Lim E, Metzger-Filho O, Winer EP (2012) The natural history of hormone receptor-positive breast cancer. Oncology (Williston Park) 26(8):688-694, 696

Mackey J, Ramos-Vazquez M, Lipatov O, McCarthy N, Kraznozhon D, Semiglazov V, Manikhas A, Gelmon K, Konecny G, Webster M (2013) Primary results of ROSE/TRIO-12, a randomized placebo controlled phase III trial evaluating the addition of ramucirumab to first-line docetaxel chemotherapy in metastatic breast cancer. Cancer Res 73(24 Supplement):abstr S5-04

Marty M, Cognetti F, Maraninchi D, Snyder R, Mauriac L, Tubiana-Hulin M, Chan S, Grimes D, Anton A, Lluch A, Kennedy J, O'Byrne K, Conte P, Green M, Ward C, Mayne K, Extra JM (2005) Randomized phase II trial of the efficacy and safety of trastuzumab combined with docetaxel in patients with human epidermal growth factor receptor 2-positive metastatic breast cancer administered as first-line treatment: the M77001 study group. J Clin Oncol 23(19):4265-4274

Miles DW, Chan A, Dirix LY, Cortes J, Pivot X, Tomczak P, Delozier T, Sohn JH, Provencher L, Puglisi F, Harbeck N, Steger GG, Schneeweiss A, Wardley AM, Chlistalla A, Romieu G (2010) Phase III study of bevacizumab plus docetaxel compared with placebo plus docetaxel for the first-line treatment of human epidermal growth factor receptor 2-negative metastatic breast cancer. J Clin Oncol 28(20):3239-3247

Miller KD, Chap LI, Holmes FA, Cobleigh MA, Marcom PK, Fehrenbacher L, Dickler M, Overmoyer BA, Reimann JD, Sing AP, Langmuir V, Rugo HS (2005) Randomized phase III trial of capecitabine compared with bevacizumab plus capecitabine in patients with previously treated metastatic breast cancer. J Clin Oncol 23(4):792-799

Miller K, Wang M, Gralow J, Dickler M, Cobleigh M, Perez EA, Shenkier T, Cella D, Davidson NE (2007) Paclitaxel plus bevacizumab versus paclitaxel alone for metastatic breast cancer. N Engl J Med 357(26):2666-2676

Nadji M, Gomez-Fernandez C, Ganjei-Azar P, Morales AR (2005) Immunohistochemistry of estrogen and progesterone receptors reconsidered: experience with 5,993 breast cancers. Am J Clin Pathol 123(1):21-27

National Cancer Institute (2012) Cancer trends progress report-2011/2012 update: costs of cancer care. National Cancer Institute, NIH, DHHS. http:// progressreport.cancer.gov/doc_detail.asp?pid=1\&did=2009\&chid=95\&c oid=926\&mid=. Accessed 19 May 2014

National Cancer Institute (2013) A snapshot of breast cancer. http://www cancer.gov/researchandfunding/snapshots/breast\#footnote1. Accessed 19 May 2014

National Cancer Institute (2014) NCI dictionary of cancer terms: targeted therapy. http://www.cancer.gov/dictionary?cdrid=270742. Accessed 10 July 2014

O'Shaughnessy J, Weckstein D, Vukelja S, Mclntyre K, Krekow L, Holmes F, Asmar L, Blum J (2007) Preliminary results of a randomized phase II study of weekly irinotecan/carboplatin with or without cetuximab in patients with metastatic breast cancer. Breast Cancer Res Treat 106:S32-S33

O'Shaughnessy J, Schwartzberg L, Danso M, Rugo H, Miller K, Yardley D, Carlson R, Finn R, Charpentier E, Freese M (2011a) A randomized phase III study of iniparib (BSI-201) in combination with gemcitabine/carboplatin (G/C) in metastatic triple-negative breast cancer (TNBC). J Clin Oncol 29(15 suppl):abstr 1007

O'Shaughnessy J, Osborne C, Pippen JE, Yoffe M, Patt D, Rocha C, Koo IC, Sherman BM, Bradley C (2011b) Iniparib plus chemotherapy in metastatic triple-negative breast cancer. N Engl J Med 364(3):205-214

Paik S, Shak S, Tang G, Kim C, Baker J, Cronin M, Baehner FL, Walker MG, Watson D, Park T, Hiller W, Fisher ER, Wickerham DL, Bryant J, Wolmark N (2004) A multigene assay to predict recurrence of tamoxifen-treated, node-negative breast cancer. N Engl J Med 351(27):2817-2826

Paik S, Tang G, Shak S, Kim C, Baker J, Kim W, Cronin M, Baehner FL, Watson D, Bryant J, Costantino JP, Geyer CE Jr, Wickerham DL, Wolmark N (2006) Gene expression and benefit of chemotherapy in women with node-negative, estrogen receptor-positive breast cancer. J Clin Oncol 24(23):3726-3734

Parker JS, Mullins M, Cheang MC, Leung S, Voduc D, Vickery T, Davies S, Fauron C, He X, Hu Z, Quackenbush JF, Stijleman IJ, Palazzo J, Marron JS, Nobel AB, Mardis E, Nielsen TO, Ellis MJ, Perou CM, Bernard PS (2009) Supervised risk predictor of breast cancer based on intrinsic subtypes. J Clin Oncol 27(8):1160-1167

Perez EA, Romond EH, Suman VJ, Jeong JH, Davidson NE, Geyer CE Jr, Martino S, Mamounas EP, Kaufman PA, Wolmark N (2011) Four-year follow-up of trastuzumab plus adjuvant chemotherapy for operable human epidermal growth factor receptor 2-positive breast cancer: joint analysis of data from NCCTG N9831 and NSABP B-31. J Clin Oncol 29(25):3366-3373

Perez EA, Thompson EA, Anderson SK, Asmann YW, Kalari KR, Eckel-Passow J, Dueck AC, Tenner KS, Jen J, Fan J-B, Geiger X, McCullough AE, Chen B, Zschunke M, Jenkins RB, Sledge GW, Winer EP, Gralow J, Reinholz MM, Ballman KV (2014) Association of genomic analysis of immune function genes and clinical outcome in the NCCTG (Alliance) N9831 adjuvant trastuzumab trial. J Clin Oncol 32(15 suppl):abstr 509

Perou CM, Sorlie T, Eisen MB, van de Rijn M, Jeffrey SS, Rees CA, Pollack JR, Ross DT, Johnsen $\mathrm{H}$, Akslen LA, Fluge O, Pergamenschikov A, Williams C, Zhu SX, Lonning PE, Borresen-Dale AL, Brown PO, Botstein D (2000) Molecular portraits of human breast tumours. Nature 406(6797):747-752

Piccart-Gebhart M, Holmes A, De Azambuja E, Di Cosimo S, Swaby R, Untch M (2013) The association between event-free survival and pathological complete response to neoadjuvant lapatinib, trastuzumab or their combination in HER2-positive breast cancer. Survival follow-up analysis of the NeoALTTO study (BIG 1-06). Cancer Res 73 (24 suppl):abstr S1-01

Piccart-Gebhart MJ, Holmes AP, Baselga J, De Azambuja E, Dueck AC, Viale G, Zujewski JA, Goldhirsch A, Santillana S, Pritchard KI, Wolff AC, Jackisch C, Lang I, Untch M, Smith IE, Boyle F, Xu B, Gomez HL, Gelber RD, Perez EA (2014) First results from the phase III ALTTO trial (BIG 2-06; NCCTG [Alliance] N063D) comparing one year of anti-HER2 therapy with lapatinib alone $(L)$, trastuzumab alone $(T)$, their sequence $(T \rightarrow L)$, or their 
combination $(T+L)$ in the adjuvant treatment of HER2-positive early breast cancer (EBC). J Clin Oncol 32(15 suppl):abstr LBA4

Prat A, Parker JS, Karginova O, Fan C, Livasy C, Herschkowitz Jl, He X, Perou CM (2010) Phenotypic and molecular characterization of the claudin-low intrinsic subtype of breast cancer. Breast Cancer Res 12(5):R68

Prowell TM, Pazdur R (2012) Pathological complete response and accelerated drug approval in early breast cancer. N Engl J Med 366(26):2438-2441

Ravdin PM, Siminoff LA, Davis GJ, Mercer MB, Hewlett J, Gerson N, Parker HL (2001) Computer program to assist in making decisions about adjuvant therapy for women with early breast cancer. J Clin Oncol 19(4):980-991

Robert NJ, Dieras V, Glaspy J, Brufsky AM, Bondarenko I, Lipatov ON, Perez EA, Yardley DA, Chan SY, Zhou X, Phan SC, O'Shaughnessy J (2011) RIBBON-1: randomized, double-blind, placebo-controlled, phase III trial of chemotherapy with or without bevacizumab for first-line treatment of human epidermal growth factor receptor 2-negative, locally recurrent or metastatic breast cancer. J Clin Oncol 29(10):1252-1260

Robidoux A, Tang G, Rastogi P, Geyer CE, Azar CA, Atkins JN, Fehrenbacher L, Bear HD, Baez-Diaz L, Kuebler JP (2012) Evaluation of lapatinib as a component of neoadjuvant therapy for HER2 + operable breast cancer: NSABP protocol B-41. J Clin Oncol 30(18 Suppl):812

Ross JS, Slodkowska EA, Symmans WF, Pusztai L, Ravdin PM, Hortobagyi GN (2009) The HER-2 receptor and breast cancer: ten years of targeted antiHER-2 therapy and personalized medicine. Oncologist 14(4):320-368

Rutgers E, Piccart-Gebhart MJ, Bogaerts J, Delaloge S, Veer LV, Rubio IT, Viale G, Thompson AM, Passalacqua R, Nitz U, Vindevoghel A, Pierga JY, Ravdin PM, Werutsky G, Cardoso F (2011) The EORTC 10041/BIG 03-04 MINDACT trial is feasible: results of the pilot phase. Eur J Cancer 47(18):2742-2749

Slamon DJ, Leyland-Jones B, Shak S, Fuchs H, Paton V, Bajamonde A, Fleming T, Eiermann W, Wolter J, Pegram M, Baselga J, Norton L (2001) Use of chemotherapy plus a monoclonal antibody against HER2 for metastatic breast cancer that overexpresses HER2. N Engl J Med 344(11):783-792

Sorlie T, Perou CM, Tibshirani R, Aas T, Geisler S, Johnsen H, Hastie T, Eisen MB, van de Rijn M, Jeffrey SS, Thorsen T, Quist H, Matese JC, Brown PO, Botstein D, Lonning PE, Borresen-Dale AL (2001) Gene expression patterns of breast carcinomas distinguish tumor subclasses with clinical implications. Proc Natl Acad Sci USA 98(19):10869-10874

Stewart DJ, Whitney SN, Kurzrock R (2010) Equipoise lost: ethics, costs, and the regulation of cancer clinical research. J Clin Oncol 28(17):2925-2935

Swain S, Kim S-B, Cortes J, Ro J, Semiglazov V, Campone M, Ciruelos E, Ferrero J-M, Schneeweiss A, Knott A, Clark E, Ross G, Benyunes M, Baselga J (2012) Confirmatory Overall Survival (OS) Analysis of CLEOPATRA: A Randomized, Double-Blind, Placebo-Controlled Phase III Study with Pertuzumab (P), Trastuzumab (T), and Docetaxel (D) in Patients (pts) with HER2-Positive First-Line (1L) Metastatic Breast Cancer (MBC). Presented at the San Antonio Breast Cancer Symposium, San Antonio, TX, December 4-8, 2012. http://www.abstracts2view.com/sabcs12/viewp.php?nu=P5-18-26 (Poster and Abstract P5-18-26). Accessed 19 Feb 2013

Swain SM, Kim SB, Cortes J, Ro J, Semiglazov V, Campone M, Ciruelos E, Ferrero JM, Schneeweiss A, Knott A, Clark E, Ross G, Benyunes MC, Baselga J (2013) Pertuzumab, trastuzumab, and docetaxel for HER2-positive metastatic breast cancer (CLEOPATRA study): overall survival results from a randomised, double-blind, placebo-controlled, phase 3 study. Lancet Oncol 14(6):461-471
The Nolvadex Adjuvant Trial Organisation (1985) Controlled trial of tamoxifen as single adjuvant agent in management of early breast cancer. Analysis at six years by Nolvadex Adjuvant Trial Organisation. Lancet 1(8433):836-840

Turner NC, Ro J, Andre F, Loi S, Verma S, Iwata H, Harbeck N, Loibl S, Huang Bartlett C, Zhang K, Giorgetti C, Randolph S, Koehler M, Cristofanilli M (2015) Palbociclib in Hormone-Receptor-Positive Advanced Breast Cancer. N Engl J Med 373(3):209-219

van 't Veer LJ, Dai H, van de Vijver MJ, He YD, Hart AA, Mao M, Peterse HL, van der Kooy K, Marton MJ, Witteveen AT, Schreiber GJ, Kerkhoven RM, Roberts C, Linsley PS, Bernards R, Friend SH (2002) Gene expression profiling predicts clinical outcome of breast cancer. Nature 415(6871):530-536

van de Vijver MJ, He YD, van't Veer L, Dai H, Hart AA, Voskuil DW, Schreiber GJ, Peterse $\mathrm{J}$, Roberts C, Marton MJ, Parrish M, Atsma D, Witteveen A, Glas A, Delahaye L, van der Velde T, Bartelink H, Rodenhuis S, Rutgers ET, Friend SH, Bernards R (2002) A gene-expression signature as a predictor of survival in breast cancer. N Engl J Med 347(25):1999-2009

Verma S, Miles D, Gianni L, Krop IE, Welslau M, Baselga J, Pegram M, Oh DY, Dieras V, Guardino E, Fang L, Lu MW, Olsen S, Blackwell K (2012) Trastuzumab emtansine for HER2-positive advanced breast cancer. N Engl J Med 367(19):1783-1791

Viale G, Slaets L, Bogaerts J, Rutgers E, Veer L, Piccart-Gebhart MJ, de Snoo FA, Stork-Sloots L, Russo L, Dell'Orto P, van den Akker J, Glas A, Cardoso F (2014) High concordance of protein (by IHC), gene (by FISH; HER2 only), and microarray readout (by TargetPrint) of ER, PgR, and HER2: results from the EORTC 10041/BIG 03-04 MINDACT trial. Ann Oncol 25(4):816-823

Vogel CL, Cobleigh MA, Tripathy D, Gutheil JC, Harris LN, Fehrenbacher L, Slamon DJ, Murphy M, Novotny WF, Burchmore M, Shak S, Stewart SJ, Press M (2002) Efficacy and safety of trastuzumab as a single agent in first-line treatment of HER2-overexpressing metastatic breast cancer. J Clin Oncol 20(3):719-726

von Minckwitz G, du Bois A, Schmidt M, Maass N, Cufer T, de Jongh FE, Maartense E, Zielinski C, Kaufmann M, Bauer W, Baumann KH, Clemens MR, Duerr R, Uleer C, Andersson M, Stein RC, Nekljudova V, Loibl S (2009) Trastuzumab beyond progression in human epidermal growth factor receptor 2-positive advanced breast cancer: a german breast group 26/ breast international group 03-05 study. J Clin Oncol 27(12):1999-2006

Wishart GC, Bajdik CD, Azzato EM, Dicks E, Greenberg DC, Rashbass J, Caldas C, Pharoah PD (2011) A population-based validation of the prognostic model PREDICT for early breast cancer. Eur J Surg Oncol 37(5):411-417

Yin W, Jiang Y, Shen Z, Shao Z, Lu J (2011) Trastuzumab in the adjuvant treatment of HER2-positive early breast cancer patients: a meta-analysis of published randomized controlled trials. PLOS ONE 6(6):e21030

\section{Submit your manuscript to a SpringerOpen ${ }^{\circ}$ journal and benefit from:}

- Convenient online submission

- Rigorous peer review

- Immediate publication on acceptance

- Open access: articles freely available online

- High visibility within the field

- Retaining the copyright to your article

Submit your next manuscript at springeropen.com 